\title{
Role of the active cycle of breathing technique combined with phonophoresis for the treatment of patients with chronic obstructive pulmonary disease (COPD): study protocol for a preliminary randomized controlled trial
}

M. D. Shen, L. R. Guo, Y. W. Li, R. T. Gao, X. Sui, Z. Du, L. Q. Xu, H. Y. Shi, Y. Y. Ni, X. Zhang, Y. Pang, W. Zhang,

T. Z. Yu and F. Li

\begin{abstract}
Background: Chronic obstructive pulmonary disease (COPD) is a chronic inflammatory lung disease characterized by coughing, the production of excess sputum, and dyspnea. Patients with excessively thick sputum may have frequent attacks or develop more serious disease. The guidelines recommend airway clearance for patients with excessive sputum who are hospitalized with COPD. The active cycle of breathing technique is the most common non-pharmacological airway clearance technique used by physiotherapists. However, the effectiveness of the technique is not always guaranteed. Active cycle of breathing techniques require the initial dilution of the sputum, usually by inhalation drugs, which may have limited effects. Recent studies have found that phonophoresis decreases inflammation, suggesting the potential of the combined usage of active cycle of breathing techniques and phonophoresis. Therefore, the aim of this study is to explore the effectiveness and safety of combining active cycle of breathing technique and phonophoresis in treating COPD patients.

Methods and analysis: We propose a single-blind randomized controlled trial using 75 hospitalized patients diagnosed with COPD with excessive sputum production. The patients will be divided into three groups. The intervention group will receive active cycle of breathing techniques combined with phonophoresis. The two comparison groups will be treated with active cycle of breathing techniques and phonophoresis, respectively. The program will be implemented daily for 1 week. The primary outcomes will be changes in sputum viscosity and production, lung function, and pulse oximetry. Secondary outcomes include the assessment of COPD and anxiety, measured by the COPD Assessment Test scale and the Anxiety Inventory for Respiratory Disease, respectively; selfsatisfaction; the degree of cooperation; and the length of hospital stay. All outcome measures, with the exception (Continued on next page)
\end{abstract}

* Correspondence: fli@jlu.edu.cn

School of Nursing, Jilin University, No 965, Xin Jiang Avenue, Changchun 130000, Jilin Province, China

C C The Author(s). 2021 Open Access This article is licensed under a Creative Commons Attribution 4.0 International License, which permits use, sharing, adaptation, distribution and reproduction in any medium or format, as long as you give appropriate credit to the original author(s) and the source, provide a link to the Creative Commons licence, and indicate if changes were made. The images or other third party material in this article are included in the article's Creative Commons licence, unless indicated otherwise in a credit line to the material. If material is not included in the article's Creative Commons licence and your intended use is not permitted by statutory regulation or exceeds the permitted use, you will need to obtain permission directly from the copyright holder. To view a copy of this licence, visit http://creativecommons.org/licenses/by/4.0/ The Creative Commons Public Domain Dedication waiver (http://creativecommons.org/publicdomain/zero/1.0/) applies to the data made available in this article, unless otherwise stated in a credit line to the data. 
(Continued from previous page)

of sputum production and additional secondary outcomes, will be assessed at the commencement of the study and after 1 week's intervention. Analysis of variance will be used to investigate differences between the groups, and a $p$-value of less than 0.05 (two-tailed) will be considered statistically significant.

Discussion: This study introduces a combination of active cycle of breathing techniques and phonophoresis to explore the impact of these interventions on patients hospitalized with COPD. If this combined intervention is shown to be effective, it may prove to be a better treatment for patients with COPD.

Trial registration: The trial was registered prospectively on the Chinese Clinical Trial Registry on 24 December 2019.ClinicalTrials.gov ChiCTR1900028506. Registered on December 2019.

Keywords: Airway cycle of breathing techniques, Phonophoresis, Chronic obstructive pulmonary disease, Protocol, Randomized controlled trial

\section{Article summary}

Strengths and limitations of this study:

1. The use of phonophoresis in treating COPD patients is poorly documented.

2. The combination of active cycle of breathing techniques and phonophoresis is novel.

3. Study personnel are experienced physicians, rehabilitators, and caregivers, providing practical guidance for the research.

4. We propose a single-center randomized clinical trial. It is unclear whether our findings will be generalizable to other locations and clinical settings. However, the large geographic, cultural, and socioeconomic diversity of the inpatients may help to reduce this potential bias.

\section{Introduction}

According to the statistics of the Global Burden of Disease Study, chronic obstructive pulmonary disease (COPD) has a high prevalence, as well as high mortality and morbidity [1-7]. In China alone, in 2015, nearly 100 million people were suffering from COPD [8]. Furthermore, the medical expenses of patients with COPD are increasing, resulting in a heavier economic burden. At present, COPD has become a global public health problem.

Cough, sputum production, and dyspnea are the main symptoms of COPD [9, 10]. Patients with excessively thick sputum may suffer frequent attacks or be prone to more serious disease [11]. To address the problem of excessive viscous sputum in patients hospitalized with COPD, the American Association for Respiratory Care (AARC) published the "AARC clinical practice guideline: effectiveness of non-pharmacologic airway clearance therapies in hospitalized patients." This guideline [12] describes the necessity for airway clearance in such patients. A cross-sectional survey [13] in Sweden showed that $75 \%$ of physiotherapists prescribed airway clearance treatments for most COPD patients, and most physiotherapists (89\%) believe that sputum clearance is an important aspect of the overall management of COPD patients. Of the various nonpharmacologic airway clearance techniques, active cycle of breathing techniques are the most commonly used by physiotherapists [14]. A systematic review [15] shows that the active cycle of breathing technique can improve lung function, levels of arterial blood gases, perceived levels of dyspnea, and quality of life. In addition, the systematic reviews of Cabillic et al. [16] and Ides et al. [17] observed that the active cycle of breathing technique was an effective treatment for patients with COPD, with a grade B level of evidence, in comparison to other airway clearance techniques.

Both expectoration and reducing lung inflammation are necessary in treating COPD. Phonophoresis is a physical therapy technique that combines ultrasound and topical medications [18]. It has been proven to decrease inflammatory infiltration [19] through the absorption of ultrasonic energy and cavitation [20] and has been widely studied as a non-invasive method of medication administration [21]. There is ample evidence showing that phonophoresis is both more effective and leads to greater patient compliance [22] than conventional methods for administering medication. Recent studies have demonstrated the efficacy of phonophoresis in the treatment of acute calcific tendinitis of the shoulder [23], chronic nonbacterial prostatitis [24], and chronic rhinosinusitis [25], among other diseases. At present, COPD patients in the Medical Center in Changchun, China, mostly use inhalation therapy to dilute the sputum. We propose exploring the use of phonophoresis combined with active cycle of breathing techniques to relieve the respiratory symptoms of COPD patients, which may be more effective than the use of a single treatment. To our knowledge, there are no reports of the use of this combined therapy for COPD. The aim of this single-blind, three-arm, randomized controlled trial, therefore, is to investigate combining active cycle of breathing techniques and phonophoresis in treating patients hospitalized with COPD. 


\section{Methods}

\section{Study design}

This is a single-blind, three-arm, randomized controlled trial. The intervention group will receive active cycle of breathing techniques combined with phonophoresis and control group 1 will receive active cycle of breathing only, while control group 2 will receive phonophoresis only. By comparing these three groups, we hope to explore the benefits of a combined program, compared to a single intervention. For the three-armed trial [26], COPD patients will receive active cycle of breathing techniques during hospitalization. Because the mean length of hospital stay for COPD patients in our medical center is 1 week, the duration of the intervention in our study will be set at 1 week. The trial will be conducted at the Medical Center in Changchun, China. In line with the recommendations of the Protocol Items Recommendations for Interventional Trials (SPIRIT) guidelines [27], our research protocol has been registered with the China Clinical Trial Registration (ChiCTR1900028506) and has been approved by the Ethics Committee of Jilin University (2019122301). We expect to begin recruitment in December 2019 and end in June 2021. Any changes to the plan will be negotiated with trial participants and the ethics committee. A copy of the revised protocol will be sent to the patient involvement branch of the ethics committee to add to the Investigator Site File, and any deviations from the protocol will be fully documented using a breach report form.

\section{Eligibility and recruitment}

Participants in this study are patients with COPD admitted to the Department of Respiratory Medicine, Affiliated Hospital of Jilin University. The inclusion and exclusion criteria are shown below.

Inclusion criteria:

(1) Hospitalized patients diagnosed with COPD according to the Global Initiative for Chronic

Obstructive Lung Disease criteria

(2) Patients with clear consciousness, stable vital signs, and the ability to cooperate

(3) Patients who have given informed consent

(4) Adult patients

(5) Patients with a sputum viscosity classified by the same person as grade II or grade III which is characterized by the loss of humidifying function in the upper respiratory tract, as well as the loss of the mucociliary transport function, and impaired expectoration [28]

Exclusion criteria:

(1) Presence of neuromuscular disease or terminal disease
(2) Presence of asthma or other respiratory diseases

(3) History of thoracic and abdominal trauma and surgery

(4) Presence of skin infection at the site of contact

(5) Presence of a cardiac pacemaker, artificial stent, artificial valve, or heart failure

(6) Presence of acute exacerbation of COPD or on a rehabilitation program

Patients meeting inclusion and exclusion criteria will be invited to participate in our research. Informed consent will be obtained from each participant. The recruitment process will be handled by an independent caregiver who is not involved in other procedures at the Medical Center in Changchun, China.

\section{Groups}

Intervention group: active cycle of breathing techniques combined with phonophoresis

These patients will receive both active cycle of breathing techniques and phonophoresis during the 1-week intervention period. The active cycle of breathing technique consists of three main components [15]: breathing control, a thoracic expansion exercise, and a forced expiration technique.

Breathing control Patients sit comfortably in a chair and breathe normally using the lower chest.

Thoracic expansion exercise The physical therapist rests one hand on the epigastrium and guides the patients to breathe slowly and deeply using the lower chest. This is followed by holding the breath for $2 \mathrm{~s}$ and breathing out fully. This is repeated two or three times before returning to breathing control.

Forced expiration technique The physical therapist guides the patient to inhale deeply, while simultaneously contracting the abdominal muscles and keeping the mouth and throat open. The patient then holds their breath for $2 \mathrm{~s}$ followed by vigorous exhalation, making a "ha" sound to stimulate coughing. The patient then returns to breathing control until ready to begin another cycle. Within 1 week of the intervention, each patient in this group will receive the active cycle breathing technique twice daily administered by the same physical therapist.

The phonophoresis procedures were developed by respiratory physicians, rehabilitators, caregivers, and other stakeholders. In this study, they will be led by the same experienced respiratory physician in the hospital who will not be involved in the active cycle of breathing technique. The physician checks the equipment and prepares a sterile patch before starting. Next, acetylcysteine is 
placed onto the sterile patch. Patients are auscultated and marked by the same experienced respiratory physician to determine the location of sputum accumulation. The emitter and the patch with the liquid are then applied in the marked position. The frequency will be adjusted to $20 \mathrm{kHz}$, with a depth of $10 \mathrm{~mm}-150 \mathrm{~mm}$ and intensity of $0.8 \mathrm{~W} / \mathrm{cm}^{2}$, and treatment will continue for $20 \mathrm{~min}$. This procedure is performed twice a day during the intervention period. If the patient has skin burns or intolerance during the execution, stop the intervention immediately.

\section{Comparison group 1: active cycle of breathing technique}

Comparison group 1 will receive the same active cycle of breathing, composed of breathing control, the thoracic expansion exercise, and forced expiration, as the intervention group. This is also performed twice daily during the 1-week intervention period, for a duration of $20 \mathrm{~min}$ per cycle. These patients will receive mucolytic agents by inhalation.

\section{Comparison group 2: phonophoresis}

The phonophoresis conductance instrument (NAVA01TD) is used to administer the drug in the hospitalized COPD patients, using the same mucolytic agents that are used for the intervention group. The patients will undergo phonophoresis twice daily during the 1-week intervention period for $20 \mathrm{~min}$ each time.

\section{Outcome measurements}

Outcome measures will be collected and analyzed by researchers blinded to the patients' group allocation. All assessments will be performed at the commencement of the study and after the 1-week intervention, with the exception of assessments for sputum production and certain additional secondary outcomes (Fig. 1). Sputum production will be assessed after the 1-h intervention session and every $24 \mathrm{~h}$ during the week-long intervention period. Additional secondary outcomes will be collected only at the conclusion of the intervention. A summary of the outcome measures for the study is outlined in Table 1.

\section{Primary outcomes}

The first primary outcome will be sputum viscosity calculated using a viscometer $[29,30]$. After the collection of sputum from patients, in line with the instructions, the assistant will insert the sputum into the rotor in the viscometer and read the digital output. The sputum viscosity is calculated by the formula (sputum viscosity= viscometer reading $\times 10$ ). Patients will be given calibrated containers [31] at the baseline visit and instructed to collect $24 \mathrm{~h}$ worth of sputum in the container, between 07:00 each morning and 07:00 the following morning. The outcome assessor will observe and record the volumes of sputum at the 1 - and 24-h time points daily during the intervention period.

We hope to reduce obstruction by clearing the sputum in the respiratory tract. Therefore, we will use the same pulmonary function meter to perform a complete spirometry assessment before and after the intervention [32]. Vital capacity can reflect the obstruction of pulmonary function and airway obstruction will be determined by $\mathrm{FEV}_{1} \%$. The relation between expiration in the first second of forced expiration $\left(\mathrm{FEV}_{1}\right)$ and the full forced vital capacity (FVC) will be represented by $\mathrm{FEV}_{1} \%$, with normal values being approximately $75 \%$. Generally speaking, the $\mathrm{FEV}_{1} \%$ of COPD patients is less than $70 \%$. We are investigating whether this can be improved. The outcome assessor will only record vital capacity and $\mathrm{FEV}_{1} \%$ from the spirometry. We will follow the recommendations of the American Thoracic Society and European Respiratory Society [33] in the lung function test. Patients will be assessed between three and eight times, and the three best measurements with variability of less than $5 \%$ or $200 \mathrm{ml}$ will be recorded [34].

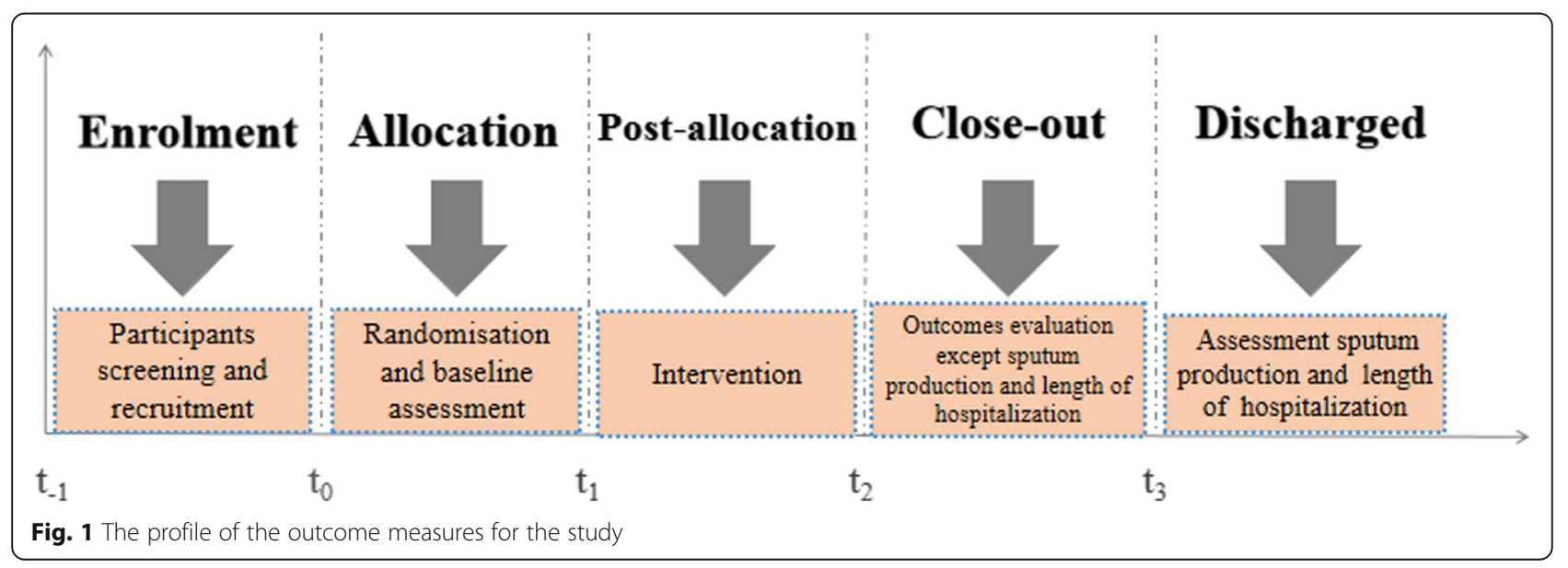


Table 1 Time points of our research

\begin{tabular}{|c|c|c|c|c|c|}
\hline & \multicolumn{5}{|c|}{ Study Period } \\
\hline & Enrolment & Allocation & Post-allocation & Close-out & Discharged \\
\hline Timepoint & $t_{-1}$ & $\mathrm{t}_{0}$ & $\mathrm{t}_{1}$ (one week) & $t_{2}$ & $t_{3}$ \\
\hline Enrolment: & & & & & \\
\hline $\begin{array}{l}\text { Eligibility } \\
\text { screen }\end{array}$ & $x$ & & & & \\
\hline $\begin{array}{l}\text { Informed } \\
\text { consent }\end{array}$ & $x$ & & & & \\
\hline Allocation & & $x$ & & & \\
\hline Intervention: & & & & & \\
\hline ACBT & & $\leftarrow$ & & $\rightarrow$ & \\
\hline phonophoresis & & $\leftarrow$ & & $\Rightarrow$ & \\
\hline $\begin{array}{l}\mathrm{ACBT}+\text { phonoph } \\
\text { oresis }\end{array}$ & & $\leftarrow$ & & & \\
\hline Assessment: & & & & & \\
\hline sputum viscosity & & $x$ & & $x$ & \\
\hline $\begin{array}{l}\text { amount of } \\
\text { sputum }\end{array}$ & & $x$ & & $x$ & \\
\hline $\begin{array}{c}\text { Vital capacity } \\
\text { FEV }_{1} \%\end{array}$ & & $x$ & & $x$ & \\
\hline $\mathrm{SpO}_{2}$ & & $x$ & & $x$ & \\
\hline CAT scale & & $x$ & & $x$ & \\
\hline AIR scale & & $x$ & & $x$ & \\
\hline Self-satisfaction & & & & $x$ & \\
\hline $\begin{array}{c}\text { period of } \\
\text { hospitalization }\end{array}$ & & & & & $x$ \\
\hline
\end{tabular}

ACBT active cycle of breathing technique, $F E V 1 \%$ forced expiratory volume in $1 \mathrm{~s}$ to the forced vital capacity, $\mathrm{SpO}_{2}$ arterial oxygen saturation, CAT scale COPD Assessment Test scale, AIR scale Anxiety Inventory for Respiratory Disease scale, $t_{-1}$ enrolment, $t_{0}$ baseline, $t_{1} 1$ week, $t_{2}$ intervention close-out, $t_{3}$ discharged

The oxygen saturation of COPD patients will be expressed as $\mathrm{SpO}_{2}$. Similarly, $\mathrm{SpO}_{2}$ will be determined by pulse oximetry from the right middle finger [35-37] before and after the intervention. Since $\mathrm{SpO}_{2}$ is also a variable parameter, the patient will receive three evaluations and the average of the results recorded.

\section{Secondary outcomes}

The COPD Assessment Test scale (CAT scale) is a simple tool for assessing the health-related quality of life in COPD patients and is the recommended questionnaire in the global strategy for the diagnosis, management, and prevention of COPD [38]. Higher scores indicate a poorer outcome [39, 40]. The scale consists of eight points. Anxiety in patients with COPD will be assessed by the Anxiety Inventory for Respiratory Disease scale (AIR scale) [41]. The scale has ten points (score range, 0 [best]-30 [worst]), and a score of greater than eight indicates a high level of anxiety [42].

\section{Additional secondary outcomes}

Patient self-satisfaction, degree of cooperation, and the length of hospital stay will be additional secondary outcomes. Improvement in the patients' condition, as well as their perception of the effectiveness of the interventions, will be evaluated by self-report on a scale of 0 to 
100. After the intervention, the patients' self-satisfaction will be scored on a 5-point Likert scale with 0 indicating "dissatisfied" and 4 meaning "very satisfied." In addition, the proportion of patients who complete treatment during the study period will be used as the measure of their degree of cooperation [43]. These statistics will be compiled in the absence of the patient. The length of hospital stay will be measured in days [44].

\section{Sample size}

Since the trial was designed with three arms, analysis of variance was chosen to calculate the sample size. We will have $90 \%$ power at the significance level (alpha) of 0.15 with an effect size of 0.4 to detect significant differences in sputum viscosity. Based on previous studies [45, 46], we assume that the dropout rate of our trial will be about $20 \%$ after the week-long intervention. Thus, the total sample size was 75 , with 25 patients in each of the three groups. The sample size was calculated using the software PASS 2019.

\section{Randomization, blinding, and allocation concealment}

We will screen 75 patients in strict accordance with the inclusion or exclusion criteria and then randomly divide them into three groups by computer-assisted block randomization stratified by disease severity. The random grouping will be performed by independent individuals who are not involved in the recruitment process. Sealed opaque envelopes will be used to conceal the patient distribution. Given the nature of the study, neither the intervention practitioner nor the participant can be blinded to the treatment plan, so blinding is only applicable for the data collection and evaluation. Neither patients nor the public will be involved in the design, conduct, reporting, or dissemination plans of our research. An illustration is shown in Fig. 2, and the time points are shown in Table 1.

\section{Data collection, management, and analysis}

All patients' data will be recorded by trained clinical researchers using a standardized case report form (CRF) and saved using the EpiData electronic database. To ensure the reliability of our study, the management of this trial will be conducted by the Trial Steering Committee (TSC). Main investigators and statisticians consist of our Trial Steering Committee, who will oversee the entire trial. Meetings will be held once a month to monitor the progress of the research and to share opinions when there are problems. The measurement data will be expressed by mean $\pm \mathrm{SD}$, and the count data will be expressed by frequency and percentage. A KolmogorovSmirnov test will be performed to analyze sample normality. Within-group changes in sputum viscosity, $\mathrm{FEV}_{1} \%$, vital capacity, arterial oxygen saturation, quality of life, and the level of anxiety will be compared using a paired $t$-test or Wilcoxon test depending on the data distribution. Inter-group differences between baseline and post-intervention among the outcomes will be compared by one-way analysis of variance. According to the normality of the data distribution, a general linear model or multi-generalized linear model will be used to compare the differences between the primary and secondary outcomes after adjusting the covariates, including sociodemographic variables, such as sex, age, body mass index, smoking history, severity of disease, among others, and baseline variables. In addition, we will follow the principle of intention to treat (ITT) and use the sequence mean method to deal with the missing data to analyze the results of the comparison between groups of each outcome. To assess whether the missing data will affect the results of the study, we will compare participants who did not complete the intervention with those who completed the intervention to verify the sensitivity of the results of the trial. A two-tailed $p$-value of $<0.05$ will be taken as significant. The data from this experiment will be entered by Epidata3.1 and analyzed by SPSS 26.0 software.

\section{Monitoring of adverse events}

All adverse events that occur in our intervention will be monitored by researchers who are not involved in the data collection and have no conflicts of interest in terms of the data monitoring committee (DMC). Adverse events are defined as any untoward occurrences in study participants that are potentially related to the implementation of the study protocol. When a participant experiences an adverse event or a worsening of the disease, they will be immediately withdrawn from the trial, and statistical analysis will be performed with the existing data. The Ethics Committee will hold an annual meeting to monitor the execution of the entire trial.

\section{Patient and public involvement (PPI)}

Patients and the public will not be involved in the processes of recruiting, randomizing, allocating, conducting interventions, and collecting outcomes. However, COPD patients who are not participants in the study may be involved in the test to discover other unintended effects of phonophoresis before the start of the trial. In addition, to avoid adding to the research burden, the outcomes of the study were selected in line with the priorities and preferences of patients.

\section{Ethics and dissemination}

There is no anticipated harm and will be no compensation for trial participation. Research reports will be disseminated through scientific forums, including peerreviewed publications and presentations at national and 


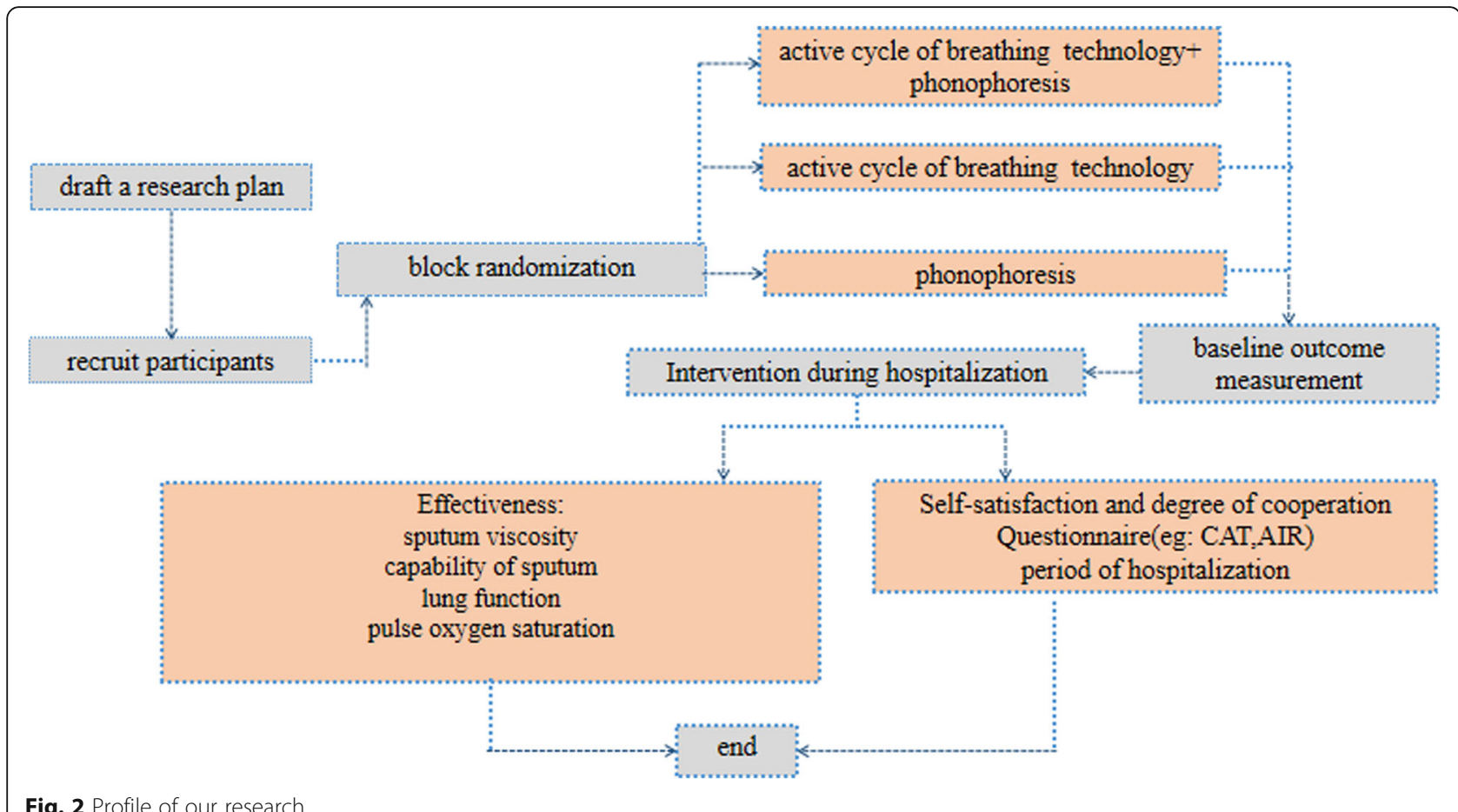

international conferences. The datasets analyzed during the current study will be available from the corresponding author on reasonable request.

\section{Discussion}

The study will explore the efficacy of a program combining the active cycle of breathing technique and phonophoresis in patients with COPD. The purpose of our study is to investigate whether the combined treatment can improve sputum viscosity, expectoration, and lung function.

Over-production and increased viscosity of sputum is common among COPD patients. Previous studies have attempted to solve these problems with active cycle of breathing techniques, without entirely satisfactory results [15-17]. It can be seen from previous reports that airway clearance is a complex process, and adequate expectoration may take a long time to resolve satisfactorily [47]. We thus propose an intervention program of active cycle of breathing techniques combined with phonophoresis to explore the best way for sputum management among COPD patients. Airway clearance techniques [48], medication [49], and rehabilitation exercise training [50] are effective in the removal of sputum. Researchers have, therefore, combined exercise training with physiotherapy applied to young patients with cystic fibrosis, a comprehensive intervention project that has resulted in significant improvements on sputum production, oxygen saturation, and short-term lung function [48]. The application of active cycle of breathing techniques combined with phonophoresis in COPD patients is not well documented. Phonophoresis can markedly enhance the effectiveness of drugs in the acute exacerbation of inflammation and pain and has received increasing attention recently [51-55]. We hope that the outcomes will be optimized by promoting more effective absorption of the drugs and the comprehensive program can play a complementary role in the treatment of COPD patients.

Due to the high incidence of COPD [8], it is likely that participants for this study will be relatively easy to recruit. In addition, the establishment of a pulmonary rehabilitation training center can provide practical guidance for the implementation of interventions. Previous research results are also able to provide us with a theoretical basis. Svenningsen et al. [45] reported a cross-over control trial of COPD airway clearance in which the loss on follow-up in the intervention and control groups was $12.50 \%$ and $18.75 \%$, respectively, while Nicolini et al. [46] found that the loss on follow-up of the intervention groups 1 and 2 and the control group were $12.50 \%, 10 \%$, and $17.50 \%$, respectively. However, the dropout rate is unlikely to be high in our study, as it is conducted in the hospital where the rate of loss of study participants is certainly lower than that outside the hospital.

There are limitations to our research. Firstly, this is a single-center randomized clinical trial, and it is unclear whether our findings are generalizable to other locations and clinical settings. Secondly, as the study is of 
relatively short duration, no data will be available beyond 1 week and longer-term effectiveness will not be able to be evaluated.

In summary, this study introduces a combination of active cycle of breathing techniques and phonophoresis to explore the impact on patients hospitalized with COPD. If this comprehensive intervention is shown to be effective, it may prove to be a better treatment for patients with COPD.

\section{Trial status}

When the manuscript is completed, the trial is in the recruitment stage. Our recruitment started in December 2019. This protocol is version 1.0, dated 25 December 2019. The end of the trial is expected in June 2021.

\section{Abbreviations}

COPD: Chronic obstructive pulmonary disease; CAT: Chronic obstructive pulmonary disease assessment test scale; AIR: Anxiety Inventory for Respiratory Disease Scale; AARC: American Association for Respiratory Care: GOLD: Global Initiative for Chronic Obstructive Lung Disease; ACBT: Active cycle of breathing technique; PPI: Patient and public involvement; FEV1\%: Forced expiratory volume in $1 \mathrm{~s}$ to forced vital capacity; $\mathrm{SpO}_{2}$ : Pulse oxygen saturation

\section{Acknowledgements}

The authors would like to thank the valuable contribution made by the patients and public representatives during the study design and intervention development.

\section{Sponsor contact information}

In our trial, the trial sponsor will conduct the investigation. The trial sponsor is Jilin University, School of Nursing. Contact name: Feng Li, PhD. The address of our sponsor is 965 Xinjiang Street, Changchun, Jilin Province, China. Email: fli@jlu.edu.cn. The sponsor plays important roles in the study design, data collection, and data analysis. We also have the responsibility for the writing of the report and the decision to submit the report for publication.

\section{Authors' contributions}

MD Shen conceived the original concept of the study and wrote the first draft of the protocol manuscript. LR Guo, YW Li, RT Gao, X Sui, Z Du, LQ Xu, HY Shi, YY Ni, X Zhang, Y Pang, W Zhang, and TZ Yu contributed to the design of the study. All authors read and approved the final manuscript. F Li conceived the original concept of the study and wrote the first draft of the protocol manuscript.

\section{Funding}

This research received no specific grant from any funding agency in the public, commercial, or not-for-profit sectors.

\section{Availability of data and materials}

The clinical data collected will not be shared with the public. However, nonclinical data will be shared with the public and other researchers.

\section{Declarations}

Ethics approval and consent to participate

This study was approved by the ethics committee of Jilin University (2019122301), and written informed consent will be obtained from each participant.

\section{Consent for publication}

Not applicable.

\section{Competing interests}

The authors declare that they have no competing interests.
Received: 9 June 2020 Accepted: 11 March 2021

Published online: 23 March 2021

\section{References}

1. Soriano JB, Abajobir AA, Abate KH, Abera SF, Agrawal A, Ahmed MB, Aichour AN, Aichour I, Aichour MTE, Alam K, Alam N, Alkaabi JM, al-Maskari F, Alvis-Guzman N, Amberbir A, Amoako YA, Ansha MG, Antó JM, Asayesh H, Atey TM, Avokpaho EFGA, Barac A, Basu S, Bedi N, Bensenor IM, Berhane A, Beyene AS, Bhutta ZA, Biryukov S, Boneya DJ, Brauer M, Carpenter DO, Casey D, Christopher DJ, Dandona L, Dandona R, Dharmaratne SD, Do HP, Fischer F, Gebrehiwot T, Geleto A, Ghoshal AG, Gillum RF, Ginawi IAM, Gupta V, Hay SI, Hedayati MT, Horita N, Hosgood HD, Jakovljevic M(M)B, James SL, Jonas JB, Kasaeian A, Khader YS, Khalil IA, Khan EA, Khang YH, Khubchandani J, Knibbs LD, Kosen S, Koul PA, Kumar GA, Leshargie CT, Liang X, el Razek HMA, Majeed A, Malta DC, Manhertz T, Marquez N, Mehari A, Mensah GA, Miller TR, Mohammad KA, Mohammed KE, Mohammed S, Mokdad AH, Naghavi M, Nguyen CT, Nguyen G, le Nguyen Q, Nguyen TH, Ningrum DNA, Nong VM, Obi J, Odeyemi YE, Ogbo FA, Oren E, PA M, Park EK, Patton GC, Paulson K, Qorbani M, Quansah R, Rafay A, Rahman MHU, Rai RK, Rawaf S, Reinig N, Safiri S, Sarmiento-Suarez R, Sartorius B, Savic M, Sawhney M, Shigematsu M, Smith M, Tadese F, Thurston GD, Topor-Madry R, Tran BX, Ukwaja KN, van Boven JFM, Vlassov W, Vollset SE, Wan X, Werdecker A, Hanson SW, Yano Y, Yimam HH, Yonemoto N, Yu C, Zaidi Z, el Sayed Zaki M, Lopez AD, Murray CJL, Vos T. Global, regional, and national deaths, prevalence, disability-adjusted life years, and years lived with disability for chronic obstructive pulmonary disease and asthma, 1990-2015: a systematic analysis for the Global Burden of Disease Study 2015. Lancet Respir Med. 2017;5(9):691-706. https://doi.org/10.1016/S2213-2600(17)30293$X$

2. Vos T, Allen C, Arora M, Barber RM, Bhutta ZA, Brown A, Carter A, Casey DC, Charlson FJ, Chen AZ, Coggeshall M, Cornaby L, Dandona L, Dicker DJ, Dilegge T, Erskine HE, Ferrari AJ, Fitzmaurice C, Fleming T, Forouzanfar MH, Fullman N, Gething PW, Goldberg EM, Graetz N, Haagsma JA, Hay SI, Johnson CO, Kassebaum NJ, Kawashima T, Kemmer L, Khalil IA, Kinfu Y, Kyu HH, Leung J, Liang X, Lim SS, Lopez AD, Lozano R, Marczak L, Mensah GA, Mokdad AH, Naghavi M, Nguyen G, Nsoesie E, Olsen H, Pigott DM, Pinho C, Rankin Z, Reinig N, Salomon JA, Sandar L, Smith A, Stanaway J, Steiner C, Teeple S, Thomas BA, Troeger C, Wagner JA, Wang H, Wanga V, Whiteford HA, Zoeckler L, Abajobir AA, Abate KH, Abbafati C, Abbas KM, Abd-Allah F, Abraham B, Abubakar I, Abu-Raddad LJ, Abu-Rmeileh NME, Ackerman IN, Adebiyi AO, Ademi Z, Adou AK, Afanvi KA, Agardh EE, Agarwal A, Kiadaliri AA, Ahmadieh H, Ajala ON, Akinyemi RO, Akseer N, al-Aly Z, Alam K, Alam NKM, Aldhahri SF, Alegretti MA, Alemu ZA, Alexander LT, Alhabib S, Ali R, Alkerwi A', Alla F, Allebeck P, al-Raddadi R, Alsharif U, Altirkawi KA, AlvisGuzman N, Amare AT, Amberbir A, Amini H, Ammar W, Amrock SM, Andersen $\mathrm{HH}$, Anderson GM, Anderson BO, Antonio CAT, Aregay AF, Ärnlöv J, Artaman A, Asayesh H, Assadi R, Atique S, Avokpaho EFGA, Awasthi A, Quintanilla BPA, Azzopardi P, Bacha U, Badawi A, Balakrishnan K, Banerjee A, Barac A, Barker-Collo SL, Bärnighausen T, Barregard L, Barrero LH, Basu A, Bazargan-Hejazi S, Beghi E, Bell B, Bell ML, Bennett DA, Bensenor IM, Benzian $H$, Berhane A, Bernabé E, Betsu BD, Beyene AS, Bhala N, Bhatt S, Biadgilign S, Bienhoff K, Bikbov B, Biryukov S, Bisanzio D, Bjertness E, Blore J, Borschmann R, Boufous S, Brainin M, Brazinova A, Breitborde NJK, Brown J, Buchbinder R, Buckle GC, Butt ZA, Calabria B, Campos-Nonato IR, Campuzano JC, Carabin H, Cárdenas R, Carpenter DO, Carrero JJ, Castañeda-Orjuela CA, Rivas JC, Catalá-López F, Chang JC, Chiang PPC, Chibueze CE, Chisumpa VH, Choi JYJ, Chowdhury R, Christensen H, Christopher DJ, Ciobanu LG, Cirillo M, Coates MM, Colquhoun SM, Cooper C, Cortinovis M, Crump JA, Damtew SA, Dandona R, Daoud F, Dargan PI, das Neves J, Davey G, Davis AC, Leo DD, Degenhardt L, Gobbo LCD, Dellavalle RP, Deribe K, Deribew A, Derrett S, Jarlais DCD, Dharmaratne SD, Dhillon PK, Diaz-Torné C, Ding EL, Driscoll TR, Duan L, Dubey M, Duncan BB, Ebrahimi H, Ellenbogen RG, Elyazar I, Endres M, Endries AY, Ermakov SP, Eshrati B, Estep K, Farid TA, Farinha CSS, Faro A, Farvid MS, Farzadfar F, Feigin VL, Felson DT, Fereshtehnejad SM, Fernandes JG, Fernandes JC, Fischer F, Fitchett JRA, Foreman K, Fowkes FGR, Fox J, Franklin RC, Friedman J, Frostad J, Fürst T, Futran ND, Gabbe B, Ganguly P, Gankpé FG, Gebre T, Gebrehiwot TT, Gebremedhin AT, Geleijnse JM, Gessner BD, Gibney KB, Ginawi IAM, Giref AZ, Giroud M, Gishu MD, Giussani G, Glaser E, Godwin WW, Gomez-Dantes H, Gona P, Goodridge A, Gopalani SV, Gotay CC, Goto A, Gouda HN, Grainger R, Greaves F, Guillemin F, Guo Y, Gupta R, Gupta R, Gupta V, Gutiérrez RA, Haile D, Hailu AD, Hailu GB, Halasa 
YA, Hamadeh RR, Hamidi S, Hammami M, Hancock J, Handal AJ, Hankey GJ, Hao Y, Harb HL, Harikrishnan S, Haro JM, Havmoeller R, Hay RJ, Heredia-Pi IB, Heydarpour P, Hoek HW, Horino M, Horita N, Hosgood HD, Hoy DG, Htet AS, Huang H, Huang JJ, Huynh C, lannarone M, Iburg KM, Innos K, Inoue M, Iyer $\mathrm{VJ}$, Jacobsen $\mathrm{KH}$, Jahanmehr $\mathrm{N}$, Jakovljevic MB, Javanbakht $M$, Jayaraman $S_{P}$, Jayatilleke $A U$, Jee $S H$, Jeemon $P$, Jensen $P N$, Jiang $Y$, Jibat $T$, Jimenez-Corona A, Jin Y, Jonas JB, Kabir Z, Kalkonde Y, Kamal R, Kan H, Karch A, Karema CK, Karimkhani C, Kasaeian A, Kaul A, Kawakami N, Keiyoro PN, Kemp AH, Keren A, Kesavachandran CN, Khader YS, Khan AR, Khan EA, Khang YH, Khera S, Khoja TAM, Khubchandani J, Kieling C, Kim P, Kim Cl, Kim D, Kim YJ, Kissoon N, Knibbs LD, Knudsen AK, Kokubo Y, Kolte D, Kopec JA, Kosen S, Kotsakis GA, Koul PA, Koyanagi A, Kravchenko M, Defo BK, Bicer BK, Kudom AA, Kuipers EJ, Kumar GA, Kutz M, Kwan GF, Lal A, Lalloo R, Lallukka T, Lam H, Lam JO, Langan SM, Larsson A, Lavados PM, Leasher JL, Leigh J, Leung R, Levi M, Li Y, Li Y, Liang J, Liu S, Liu Y, Lloyd BK, Lo WD, Logroscino G, Looker KJ, Lotufo PA, Lunevicius R, Lyons RA, Mackay MT, Magdy M, Razek AE, Mahdavi M, Majdan M, Majeed A, Malekzadeh R, Marcenes W, Margolis DJ, Martinez-Raga J, Masiye F, Massano J, McGarvey ST, McGrath JJ, McKee M, McMahon BJ, Meaney PA, Mehari A, MejiaRodriguez F, Mekonnen AB, Melaku YA, Memiah P, Memish ZA, Mendoza W, Meretoja A, Meretoja TJ, Mhimbira FA, Millear A, Miller TR, Mills EJ, Mirarefin M, Mitchell PB, Mock CN, Mohammadi A, Mohammed S, Monasta L, Hernandez JCM, Montico M, Mooney MD, Moradi-Lakeh M, Morawska L, Mueller UO, Mullany E, Mumford JE, Murdoch ME, Nachega JB, Nagel G, Naheed A, Naldi L, Nangia V, Newton JN, Ng M, Ngalesoni FN, Nguyen QL, Nisar MI, Pete PMN, Nolla JM, Norheim OF, Norman RE, Norrving B, Nunes BP, Ogbo FA, Oh IH, Ohkubo T, Olivares PR, Olusanya BO, Olusanya JO, Ortiz A, Osman M, Ota E, PA M, Park EK, Parsaeian M, de Azeredo Passos VM, Caicedo AJP, Patten SB, Patton GC, Pereira DM, Perez-Padilla R, Perico N, Pesudovs K, Petzold M, Phillips MR, Piel FB, Pillay JD, Pishgar F, Plass D, Platts-Mills JA, Polinder S, Pond CD, Popova S, Poulton RG, Pourmalek F, Prabhakaran D, Prasad NM, Qorbani M, Rabiee RHS, Radfar A, Rafay A, Rahimi K, Rahimi-Movaghar V, Rahman M, Rahman MHU, Rahman SU, Rai RK, Rajsic S, Ram U, Rao P, Refaat AH, Reitsma MB, Remuzzi G, Resnikoff S, Reynolds A, Ribeiro AL, Blancas MJR, Roba HS, Rojas-Rueda D, Ronfani L, Roshandel G, Roth GA, Rothenbacher D, Roy A, Sagar R, Sahathevan R, Sanabria JR, Sanchez-Niño MD, Santos IS, Santos JV, Sarmiento-Suarez R, Sartorius B, Satpathy M, Savic M, Sawhney M, Schaub MP, Schmidt MI, Schneider IJC, Schöttker B, Schwebel DC, Scott JG, Seedat S, Sepanlou SG, Servan-Mori EE, Shackelford KA, Shaheen A, Shaikh MA, Sharma R, Sharma U, Shen J, Shepard DS, Sheth KN, Shibuya K, Shin MJ, Shiri R, Shiue I, Shrime MG, Sigfusdottir ID, Silva DAS, Silveira DGA, singh A, singh JA, Singh OP, Singh PK, Sivonda A, Skirbekk V, Skogen JC, Sligar A, Sliwa K, Soljak M, Søreide K, Sorensen RJD, Soriano JB, Sposato LA, Sreeramareddy CT, Stathopoulou V, Steel N, Stein DJ, Steiner TJ, Steinke S, Stovner L, Stroumpoulis K, Sunguya BF, Sur P, Swaminathan S, Sykes BL, Szoeke CEl, Tabarés-Seisdedos R, Takala JS, Tandon N, Tanne D, Tavakkoli M, Taye B, Taylor HR, Ao BJT, Tedla BA, Terkawi AS, Thomson AJ, Thorne-Lyman AL, Thrift AG, Thurston GD, Tobe-Gai R, Tonelli M, Topor-Madry R, Topouzis F, Tran BX, Truelsen T, Dimbuene ZT, Tsilimbaris M, Tura AK, Tuzcu EM, Tyrovolas S, Ukwaja KN, Undurraga EA, Uneke CJ, Uthman OA, van Gool CH, Varakin YY, Vasankari T, Venketasubramanian N, Verma RK, Violante FS, Vladimirov SK, Vlassov W, Vollset SE, Wagner GR, Waller SG, Wang L, Watkins DA, Weichenthal S, Weiderpass E, Weintraub RG, Werdecker A, Westerman R, White RA, Williams HC, Wiysonge CS, Wolfe CDA, Won S, Woodbrook R, Wubshet M, Xavier D, Xu G, Yadav AK, Yan LL, Yano Y, Yaseri M, Ye P, Yebyo HG, Yip P, Yonemoto N, Yoon SJ, Younis MZ, Yu C, Zaidi Z, Zaki MES, Zeeb H, Zhou M, Zodpey S, Zuhlke LJ, Murray CJL. Global, regional, and national incidence, prevalence, and years lived with disability for 310 diseases and injuries, 1990-2015: a systematic analysis for the Global Burden of Disease Study 2015. Lancet. 2016;388(10053):1545-602. https://doi.org/10.1016/S014 0-6736(16)31678-6.

3. Lopez-Campos JL, Tan W, Soriano JB. Global burden of COPD. Respirology. 2016;21(1):14-23. https://doi.org/10.1111/resp.12660.

4. Bifan Z, Yanfang W, Jian M, et al. Disease burden of COPD in China: a systematic review. Int J Chronic Obstruct Pulmon Dis. 2018;Volume 13:135364. https://doi.org/10.2147/COPD.S161555.

5. Wang $H$, Naghavi M, Allen $C$, et al. Global, regional, and national life expectancy, all-cause mortality, and cause-specific mortality for 249 causes of death, 1980-2015: a systematic analysis for the Global Burden of Disease Study 2015. Lancet. 2016; https://doi.org/10.1016/S0140-6736(16)31012-1.
6. Murray CJ, Lopez AD. Alternative projections of mortality and disability by cause 1990-2020: Global Burden of Disease Study. Lancet. 1997;349(9064): 1498-504. https://doi.org/10.1016/S0140-6736(96)07492-2.

7. Zhou M, Wang $H$, Zeng $X$, Yin P, Zhu J, Chen W, Li X, Wang L, Wang L, Liu Y, Liu J, Zhang M, Qi J, Yu S, Afshin A, Gakidou E, Glenn S, Krish VS, MillerPetrie MK, Mountjoy-Venning WC, Mullany EC, Redford SB, Liu H, Naghavi M, Hay SI, Wang L, Murray CJL, Liang X. Mortality, morbidity, and risk factors in China and its provinces, 1990-2017: a systematic analysis for the Global Burden of Disease Study 2017. Lancet. 2019;394(10204):1145-58. https://doi. org/10.1016/S0140-6736(19)30427-1.

8. Wang C, Xu J, Yang $L$, et al. Prevalence and risk factors of chronic obstructive pulmonary disease in China (the China Pulmonary Health [CPH] study): a national cross-sectional study. Lancet. 2018; https://doi.org/10.101 6/S0140-6736(18)30841-9.

9. Javier M, Carmen CA, Eduardo MM, et al. Understanding of COPD among final-year medical students. Int J Chronic Obstruct Pulmon Dis. 2017;13:1319. https://doi.org/10.2147/COPD.S138539.

10. GOLD Committee. Global strategy for the diagnosis, management and prevention of COPD. Global Initiative for Chronic Obstructive Lung Disease (GOLD) 2017. 2018. http://goldcopd.org/gold-2017-global-strategydiagnosismanagement-prevention-copd. Accessed September 18, 2018.

11. Hastie AT, Martinez FJ, Curtis JL, Doerschuk CM, Hansel NN, Christenson S, Putcha N, Ortega VE, Li X, Barr RG, Carretta EE, Couper DJ, Cooper CB, Hoffman EA, Kanner RE, Kleerup E, O'Neal WK, Paine R III, Peters SP, Alexis NE, Woodruff PG, Han MLK, Meyers DA, Bleecker ER, Alexis NE, Anderson WH, Barr RG, Bleecker ER, Boucher RC, Bowler RP, Carretta EE, Christenson SA, Comellas AP, Cooper CB, Couper DJ, Criner GJ, Crystal RG, Curtis JL, Doerschuk CM, Dransfield MT, Freeman CM, Han MLK, Hansel NN, Hastie AT, Hoffman EA, Kaner RJ, Kanner RE, Kleerup EC, Krishnan JA, LaVange LM, Lazarus SC, Martinez FJ, Meyers DA, Newell JD Jr, Oelsner EC, O'Neal WK, Paine R III, Putcha N, Rennard SI, Tashkin DP, Scholand MB, Wells JM, Wise RA, Woodruff PG. Association of sputum and blood eosinophil concentrations with clinical measures of COPD severity: an analysis of the SPIROMICS cohort. Lancet Respir Med. 2017;5(12):956-67. https://doi.org/1 0.1016/S2213-2600(17)30432-0.

12. Strickland SL. Year in review 2014: airway clearance. Respir Care. 2015;60(4): 603-5. https://doi.org/10.4187/respcare.04095.

13. Westerdahl E, Osadnik C, Emtner M. Airway clearance techniques for patients with acute exacerbations of chronic obstructive pulmonary disease: physical therapy practice in Sweden. Chron Respir Dis. 2019;16: 147997311985586. https://doi.org/10.1177/1479973119855868.

14. Osadnik CR, McDonald CF, Holland AE. Airway clearance techniques in acute exacerbations of COPD: a survey of Australian physiotherapy practice. Physiotherapy. 2013;99(2):101-6. https://doi.org/10.1016/j.physio.2012.01.002.

15. Tang CY, Taylor NF, Blackstock FC. Chest physiotherapy for patients admitted to hospital with an acute exacerbation of chronic obstructive pulmonary disease (COPD): a systematic review. Physiotherapy. 2010;96(1):113. https://doi.org/10.1016/j.physio.2009.06.008.

16. Cabillic M, Gouilly P, Reychler G. Manual airway clearance techniques in adults and adolescents: what level of evidence? Rev Mal Respir. 2018; https://doi.org/10.1016/j.rmr.2015.12.00417.

17. Ides $K$, Vissers D, De Backer $L$, et al. Airway clearance in COPD: need for a breath of fresh air? A systematic review. COPD. 2011;8(3):196-205. https:// doi.org/10.3109/15412555.2011.560582.

18. Beutler A. Musculoskeletal therapies: adjunctive physical therapy. FP Essent. 2018:470:16-20.

19. Decha P, Kanokwan K, Jiraporn T, Pichaya J, Pisittawoot A. Phonopheresis associated with nanoparticle gel from Phyllanthus amarus relieves pain by reducing oxidative stress and proinflammatory markers in adults with knee osteoarthritis. Chin J Integr Med. 2019;25(9):691-5. https://doi.org/10.1007/ s11655-019-3202-8.

20. Park D, Park H, Seo J, Lee S. Sonophoresis in transdermal drug deliverys. Ultrasonics. 2014;54(1):56-65. https://doi.org/10.1016/j.ultras.2 013.07.007.

21. Daftardar S, Neupane R, Boddu Sai HS, et al. Advances in ultrasound mediated transdermal drug delivery. Curr Pharm Des. 2019;25(4):413-23. https://doi.org/10.2174/1381612825666190211163948.

22. Mochizuki H, Nanjo $Y$, Takahashi $H$. Better adherence to a transdermal tulobuterol patch than inhaled salmeterol in elderly chronic obstructive pulmonary disease patients. Geriatr Gerontol Int. 2013;13(2):398-404. https:// doi.org/10.1111/j.1447-0594.2012.00916.x. 
23. Chhetri RS, Khatri KP, Khanal J. Outcome of needle fenestration, subacromial steroid and diclofenac phonophoresis in acute calcific tendinitis of shoulder. JNMA J Nepal Med Assoc. 2017;56(207):357-61. https://doi.org/10.31729/ jnma.3280.

24. Tantawy SA, Elgohary HM, Kamel DM. Trans-perineal pumpkin seed oil phonophoresis as an adjunctive treatment for chronic nonbacterial prostatitis. Res Rep Urol. 2018; https://doi.org/10.2147/RRU.S167896.

25. Ansari NN, Naghdi S, Fathali M, et al. A randomized clinical trial comparing pulsed ultrasound and erythromycin phonophoresis in the treatment of patients with chronic rhinosinusitis. Physiother Theory Pract. 2015; https:// doi.org/10.3109/09593985.2014.991465.

26. Richa A, Rajeev, et al. A comparison of flutter device and active cycle of breathing techniques in acute exacerbation of chronic obstructive pulmonary disease patients. Indian J Physiother Occup Ther Int J. 2010;4:60-4.

27. Chan AW, Tetzlaff JM, Altman DG, Laupacis A, Gøtzsche PC, Krleža-Jerić K, Hróbjartsson A, Mann H, Dickersin K, Berlin JA, Doré CJ, Parulekar WR, Summerskill WSM, Groves T, Schulz KF, Sox HC, Rockhold FW, Rennie D, Moher D. SPIRIT 2013 statement: defining standard protocol items for clinical trials. Ann Intern Med. 2013;158(3):200-7. https://doi.org/10.7326/ 0003-4819-158-3-201302050-00583.

28. Yang M, Song Y, Pan L, Xie X. Evaluation of the effect of two active warming and humidifying high-flow oxygen therapy systems in patients with tracheotomy. Biomed Rep. 2019; https://doi.org/10.3892/br.2019.1219.

29. Lieberman J. Measurement of sputum viscosity in a cone-plate viscometer II. An evaluation of mucolytic agents in vitro. Am Rev Respir Dis. 1968; https://doi.org/10.1164/arrd.1968.97.4.662.

30. Ringelhann A, Juhász E, Debreczeni $L$, et al. Measurement of sputum viscosity with the Jenssen viscometer. Zeitschrift für Erkrankungen der Atmungsorgane. 1984;162(2):134-40.

31. Muñoz G, De GJ, Buxó M, et al. Long-term benefits of airway clearance in bronchiectasis: a randomised placebo-controlled trial. Eur Respir J. 2018; 51(1):1701926. https://doi.org/10.1183/13993003.01926-2017.

32. Hall GL, Irvin CG. Using lung function measurements to greater advantage in patients with lung disease: which test and when? Respirology. 2014;19(6): 780-1. https://doi.org/10.1111/resp.12331.

33. American Thoracic Society European Respiratory Society (ATS/ERS). Standardisation of spirometry. Eur Respir J. 2005; https://doi.org/10.1183/ 09031936.05.00034805.

34. Pereira CAC, Sato T, Rodrigues SC. New reference values for forced spirometry in white adults in Brazil. J Bras Pneumol. 2007;33(4):397-406. https://doi.org/10.1590/s1806-37132007000400008.

35. Basaranoglu G, Bakan M, Umutoglu T, Zengin SU, Idin K, Salihoglu Z. Comparison of $\mathrm{SpO} 2$ values from different fingers of the hands. SpringerPlus. 2015;4(1):561. https://doi.org/10.1186/s40064-015-1360-5.

36. GOLD Committee. Global strategy for the diagnosis, management and prevention of COPD. Global initiative for chronic obstructive lung disease (GOLD). Global Initiative for Chronic Obstructive Lung Disease (GOLD). 2011. http://goldcopd.org/archived-reports/. Update 2011.

37. Ascha M, Bhattacharyya A, Ramos JA, Tonelli AR. Pulse oximetry and arterial oxygen saturation during cardiopulmonary exercise testing. Med Sci Sports Exerc. 2018;50(10):1992-7. https://doi.org/10.1249/MSS.0000000000001658.

38. Gupta N, Pinto LM, Morogan A, Bourbeau J. The COPD assessment test: a systematic review. Eur Respir J. 2014;44(4):873-84. https://doi.org/10.1183/ 09031936.00025214.

39. Kocks JWH, Blom CMG, Kasteleyn MJ, et al. Feasibility and applicability of the paper and electronic COPD assessment test (CAT) and the clinical COPD questionnaire (CCQ) in primary care: a clinimetric study. NPJ Primary Care Respir Med. 2017; https://doi.org/10.1038/s41533-017-0023-0.

40. Yohannes AM, Baldwin RC, Connolly MJ. Mood disorders in elderly patients with chronic obstructive pulmonary disease. Rev Clin Gerontol. 2000;2:193202.

41. Schane RE, Walter LC, Dinno A, et al. Prevalence and risk factors for depressive symptoms in persons with chronic obstructive pulmonary disease. Gen Intern Med. 2008;23(11):1757-62. https://doi.org/10.1007/s11 606-008-0749-z.

42. Cowan J, Mulpuru S, Aaron S, Alvarez G, Giulivi A, Corrales-Medina V, Thiruganasambandamoorthy V, Thavorn K, Mallick R, Cameron DW. Study protocol: a randomized, double-blind, parallel, two-arm, placebo control tria investigating the feasibility and safety of immunoglobulin treatment in COPD patients for prevention of frequent recurrent exacerbations. Pilot Feasibility Stud. 2018;4(1):135. https://doi.org/10.1186/s40814-018-0327-z.
43. Abdulmajeed A, Michael O, Don S, et al. Impact of a COPD comprehensive case management program on hospital length of stay and readmission rates. Int J Chronic Obstruct Pulmon Dis. 2017; Volume 12:961-71. https:// doi.org/10.2147/COPD.S124385.

44. Livingston MH, Mahant S, Ratjen F, Connolly BL, Thorpe K, Mamdani M, Maclusky I, Laberge S, Giglia L, Walton JM, Yang CL, Roberts A, Shawyer AC, Brindle M, Parsons SJ, Stoian CA, Cohen E. Intrapleural dornase and tissue plasminogen activator in pediatric empyema (DTPA): a study protocol for a randomized controlled trial. Trials. 2017;18(1):293. https://doi.org/10.1186/s13 063-017-2026-0

45. Svenningsen S, Paulin GA, Sheikh K, Guo F, Hasany A, Kirby M, Etemad Rezai R, McCormack DG, Parraga G. Oscillatory positive expiratory pressure in chronic obstructive pulmonary disease. COPD: J Chron Obstruct Pulmon Dis. 2015;13(1):66-74. https://doi.org/10.3109/15412555.2015.1043523.

46. Antonello N, Valentina M, Bruna G, et al. Comparison of effectiveness of temporary positive expiratory pressure versus oscillatory positive expiratory pressure in severe COPD patients. Clin Respir J. 2018;12(3):1274-82. https:// doi.org/10.1111/crj.12661.

47. Mcilwaine MP, Lee Son NM, Richmond ML. Physiotherapy and cystic fibrosis: what is the evidence base? Curr Opin Pulm Med. 2014;20(6):613-7. https:// doi.org/10.1097/MCP.0000000000000110.

48. Kriemler S, Radtke T, Christen G, Kerstan-Huber M, Hebestreit H. Short-term effect of different physical exercises and physiotherapy combinations on sputum expectoration, oxygen saturation, and lung function in young patients with cystic fibrosis. Lung. 2016;194(4):659-64. https://doi.org/10.1 007/s00408-016-9888-x.

49. Contoli M, Pauletti A, Rossi MR, Spanevello A, Casolari P, Marcellini A, Forini G, Gnesini G, Marku B, Barnes N, Rizzi A, Curradi G, Caramori G, Morelli P, Papi A. Long-term effects of inhaled corticosteroids on sputum bacterial and viral loads in COPD. Eur Respir J. 2017;50(4):1700451. https://doi.org/1 0.1183/13993003.00451-2017.

50. Kuei-Min C, Lin-Yu L, Wei-Sheng C, et al. Efficacy of a respiratory rehabilitation exercise training package in hospitalized elderly patients with acute exacerbation of COPD: a randomized control trial. Int J Chronic Obstruct Pulmon Dis. 2015; https://doi.org/10.2147/COPD.S90673.

51. Okan S, Çağlıyan TA. Comparing the efficiency of ultrasound, ketoprofen, and mucopolysaccharide polysulfate phonophoresis in the treatment of lateral epicondylitis: a randomized-controlled clinical study. Turk J Phys Med Rehabil. 2020;66(3):307-15. https://doi.org/10.5606/tttrd.2020.4433.

52. Dorji K, Graham N, Macedo L, Gravesande J, Goldsmith CH, Gelley G, Rice M, Solomon P. The effect of ultrasound or phonophoresis as an adjuvant treatment for non-specific neck pain: systematic review of randomised controlled trials. Disabil Rehabil. 2020:1-7. https://doi.org/10.1080/096382 88.2020.1851785.

53. Papadopoulos ES, Mani R. The role of ultrasound therapy in the management of musculoskeletal soft tissue pain. Int J Low Extrem Wounds. 2020;19(4):350-8. https://doi.org/10.1177/1534734620948343.

54. Griffin AS, Cabot P, Wallwork B, Panizza B. Alternative therapies for chronic rhinosinusitis: a review. Ear Nose Throat J. 2020:014556132093941. https:// doi.org/10.1177/0145561320939415.

55. Araújo CRR, de Melo ST, Dos Santos MG, et al. Anti-inflammatory and cytotoxic activities of the extracts, fractions, and chemical constituents isolated from Luehea ochrophylla Mart. BMC Complement Altern Med. 2019;19(1):284. https://doi.org/10.1186/s12906-019-2701-7.

\section{Publisher's Note}

Springer Nature remains neutral with regard to jurisdictional claims in published maps and institutional affiliations. 